\title{
Formulation of an Ointment from Hydroethanolic Extract of Terminalia ivorensis and Therapeutic Trial on Volunteers with Moths
}

\author{
O. Sitapha ${ }^{1, *}$, N.C. Désirée Ruth ${ }^{1}$, B. Issa ${ }^{1}$, K.K. Elisée ${ }^{2}$, K.A. Koffi Mathieu ${ }^{1}$, D.A. Joseph ${ }^{1,3}$ \\ ${ }^{1}$ Biology and health Laboratory, Department of Biosciences, Félix Houphouët Boigny, Cocody (Abidjan), Ivory Coast. \\ ${ }^{2}$ Biochemistry-Microbiology laboratory, BIONAS Team, University Jean Lorougnon Guédé, Daloa, Ivory Coast. \\ ${ }^{3}$ Department of Clinical and fundamental biochemistry, Pasteur Institute, Abidjan, Ivory Coast.
}

\section{ART ICLE DETAILS}

\section{Article history:}

Received 06 October 2020

Accepted 24 October 2020

Available online 26 October 2020

\section{Keywords:}

Terminalia ivorensis

Trichophytic Clipping Moth

Microsporic Clipping Moth

\begin{abstract}
A B S T R A C T
This study was conducted to make a contribution in the treatment of dermatosis, particularly moths. Ointments of different concentrations made from the hydroethanolic extract of Terminalia ivorensis and shea butter were used. The best results were obtained with the following concentrations: C4: $0.01 \mathrm{~g} / \mathrm{mL}$; C5: $0.0125 \mathrm{~g} / \mathrm{mL}$; 6 : $0.015 \mathrm{~g} / \mathrm{mL}$ and C10: $0.025 \mathrm{~g} / \mathrm{mL}$ for trichophytic clipping moth on eleven (11) selected persons with ringworm and C9: $0.0225 \mathrm{~g} / \mathrm{mL}$ for microsporic clipping moth on one (1) person. The present study really provides the scientific basis for the use of this plant in the traditional treatment of diseases and may help to discover new chemical classes of antifungal substances that could serve as selective agents for infectious disease chemotherapy.
\end{abstract}

\section{Introduction}

The plants use for therapeutic is an ancestral practice throughout the world. Thus, for thousands of years, human being used plants found in nature to treat and cure diseases [1]. According to Michèle [2], almost all pharmaceutical products used by humans to relieve their ills are of plant origin. Indeed, plants use in phytotherapy is fomer and has a public interest. This practice is due to the accessibility and availability of traditional medicine, poverty, the high cost of modern medicines and the harmfulness of side effects caused by synthetic drugs [3-5]. All these findings justify all the actions currently being taken to develop traditional medicine and ensure its integration into national modern health care systems [5].

In addition, medicinal plants are important for pharmacological research and drug development. Their constituents can be used directly as therapeutic agents as in phytotherapy, either as starting materials for drug development or as models for the synthesis of pharmacologically active compounds [6]. Despite the evolution of medicine, some diseases such as skin diseases have not yet been eradicated from our societies. Skin diseases are very numerous, and about $70 \%$ of the population is affected by dermatosis during its lifetime. Several microorganisms are implicated in skin infections, including bacteria, viruses and especially fungi. They are the cause of skin infections in special circumstances related to the host or its environment [7].

Among the fungi involved in dermatosis, dermatophytes are predominant. These dermatophytes are fungi that have an affinity for keratin. They cause various cutaneousphaneric attacks, including moths [8]. Seen the persistence of these microorganisms and the skin problems they cause in our society, our team is committed to treating moths with an ointment made with extracts of Terminalia ivorensis A. Chev. (Combretaceae).

\section{Experimental Methods}

\subsection{Materials}

The plant material consists of Terminalia ivorensis bark, harvested in July 2019, in the courtyard of the Pasteur Institute, Ivory Coast, (IPCI) located in Cocody (Ivory Coast). The plant has been identified at the National Floristic Center (NFC) under the herbarium number 8855. Shea butter was used as an excipient. Regarding moths, there were (12) twelve cases who's eleven of trichophytic clipping moth and one person with microsporic clipping moth.

\subsection{Preparation of Total Hydroalcoholic Extract}

The bark of $T$. ivorensis was cut into small pieces and dried in a place protected from the sun and humidity for 14 days. After drying, the bark was crushed and reduced to a fine powder using a Retsch GM300 electric mill. The $70 \%$ hydroalcoholic extract was obtained according to the method developed by Zirihi et al. [9]. Thus, hundred grams $(100 \mathrm{~g})$ of vegetable powder was vigorously stirred in 1 liter of $70 \%$ ethanol using an electric mixer of the STPE 1110 brand. The macerate obtained after several stirring cycles was wrung out on a square of cloth, then filtered four times successively on cotton wool and once on Whatman No. 3 paper. The filtrate obtained is concentrated in an oven at $50^{\circ} \mathrm{C}$ for 24 hours. The powder obtained constituted the total hydroalcoholic extract (Fig. 1).

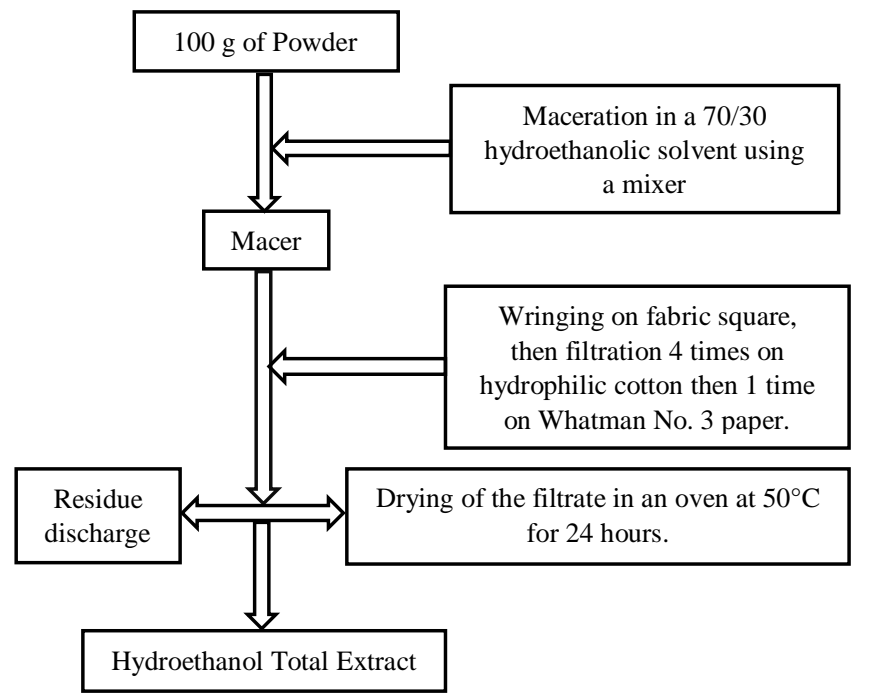

Fig. 1 Diagram of hydroethanol extraction [9] 


\subsection{Formulation of the Ointment}

Different ranges of plant extract $0.10 \mathrm{~g}$ - $1 \mathrm{~g}$ were crushed separately in a mortar porcelain and mixed with the $40 \mathrm{~mL}$ of shea butter melted on a hot plate at $40{ }^{\circ} \mathrm{C}$. The $\mathrm{pH}$ values of the ointments, shea butter and hydroethanol extract were determined.

\subsection{Method of Processing}

The treatment consisted of carrying out two (2) applications per day on the affected part over a period of 1 month that we set ourselves. The various cases were monitored regularly.

\section{Results and Discussion}

\subsection{Packing of Ointment}

Ten (10) tubes of ointments of various concentrations have been chosen. These concentrations are: $\mathrm{C} 1: 0.0025 \mathrm{~g} / \mathrm{mL}-\mathrm{C} 2: 0.005 \mathrm{~g} / \mathrm{mL}-\mathrm{C} 3$ : $0.0075 \mathrm{~g} / \mathrm{mL}$ - C4: $.0 .01 \mathrm{~g} / \mathrm{mL}$ - C5: $0.0125 \mathrm{~g} / \mathrm{mL}$ - C6: $0.015 \mathrm{~g} / \mathrm{mL}$ - C7: $0.0175 \mathrm{~g} / \mathrm{mL}$ - C8: $0.02 \mathrm{~g} / \mathrm{mL}$ - C9: $0.0225 \mathrm{~g} / \mathrm{mL}$ - C10: $0.025 \mathrm{~g} / \mathrm{mL}$. They were packaged in $60 \mathrm{~mL}$ plastic pots. These different concentrations give the ointments a variety of colour ranging from the least dark to the darkest (Fig. 2). All ointments have a semi-solid consistency. The 70\% ethanolic extract has a $\mathrm{pH}=5$; shea butter has a $\mathrm{pH}=5.56$ and the formulated ointment has a $4.30<\mathrm{pH}<4.93$ according on the pot.
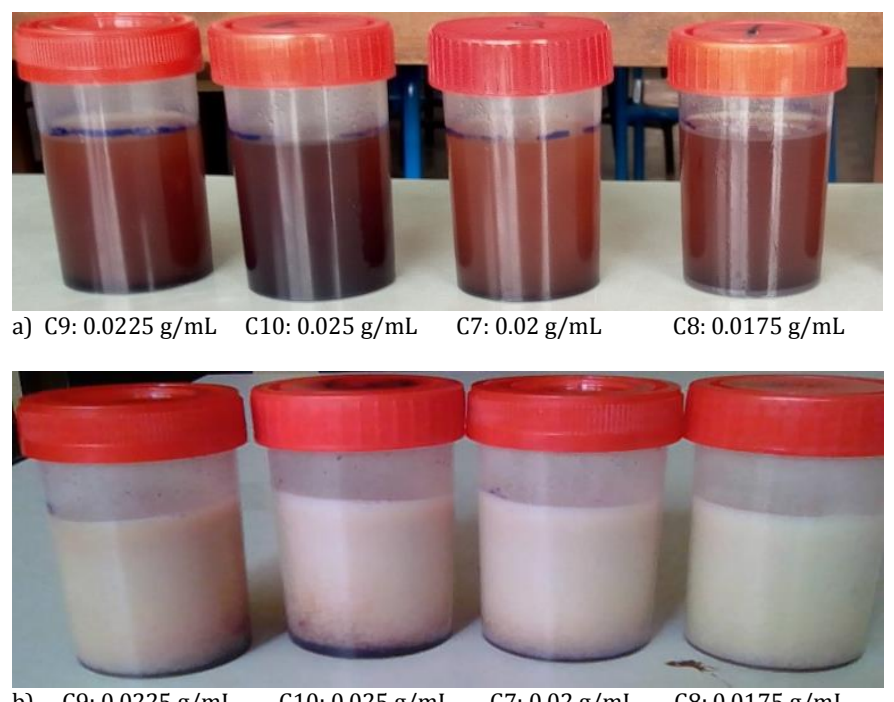

$\begin{array}{llll}\text { b) } \quad \text { C9: } 0.0225 \mathrm{~g} / \mathrm{mL} & \mathrm{C} 10: 0.025 \mathrm{~g} / \mathrm{mL} \quad \text { C7: } 0.02 \mathrm{~g} / \mathrm{mL} \quad \text { C8: } 0.0175 \mathrm{~g} / \mathrm{mL}\end{array}$

Fig. 2 Formulated ointment a) liquid state and b) solid state

\subsection{Treatment}

Subjects who applied the ointment saw an improvement in the treatment of their skin conditions after three days. After 21 days on average, healing was observed. Twelve (12) patients, whose ages ranged from 5 to 16 years old, had a dermatophyte of the scalp, called tricophytic clipping moth. The lesions are represented by several small patches of alopecia of 1 to $2 \mathrm{~mm}$ spread over the entire scalp (Figs. 3B and 3C). A microsporic clipping moth was also diagnosed in a 3 years and half patient. The lesions present a large alopecia plaque 2 to $5 \mathrm{~cm}$ in diameter (Fig. 3A).

The concentrations used allowed the patients to be cured after an average of 21 days. The results obtained after treatment are summarized in Table 1.

Table 1 Results of treatment with the ointment

\begin{tabular}{|c|c|c|c|c|}
\hline $\begin{array}{l}\text { No. of treated } \\
\text { patients }\end{array}$ & $\begin{array}{l}\text { Types of } \\
\text { affections }\end{array}$ & $\begin{array}{l}\text { Duration of } \\
\text { treatment }\end{array}$ & $\begin{array}{l}\text { Concentrations } \\
\text { used }\end{array}$ & $\begin{array}{l}\text { Extent of } \\
\text { Affection }\end{array}$ \\
\hline$\overline{11}$ & $\begin{array}{l}\text { Trichophytic } \\
\text { clipping moth }\end{array}$ & $\begin{array}{l}28 \text { days } \\
21 \text { days } \\
30 \text { days } \\
60 \text { days }\end{array}$ & $\begin{array}{l}\mathrm{C} 1: 0.0025 \mathrm{~g} / \mathrm{mL} \\
\mathrm{C} 2: 0.005 \mathrm{~g} / \mathrm{mL} \\
\mathrm{C} 3: 0.0075 \mathrm{~g} / \mathrm{mL} \\
\mathrm{C} 4: 0.01 \mathrm{~g} / \mathrm{mL} \\
\text { C5 }: 0.0125 \mathrm{~g} / \mathrm{mL} \\
\mathrm{C} 6: 0.015 \mathrm{~g} / \mathrm{mL} \\
\mathrm{C} 7: 0.0175 \mathrm{~g} / \mathrm{mL} \\
\mathrm{C} 8: 0.02 \mathrm{~g} / \mathrm{mL} \\
\mathrm{C} 10: 0.025 \mathrm{~g} / \mathrm{mL}\end{array}$ & $\begin{array}{l}\text { Several small } \\
\text { plates almost } \\
\text { all over the } \\
\text { head }\end{array}$ \\
\hline 1 & $\begin{array}{l}\text { Microsporic } \\
\text { clipping moth }\end{array}$ & 30 days & C9: $0.0225 \mathrm{~g} / \mathrm{mL}$ & $\begin{array}{l}\text { A big plate on } \\
\text { the head }\end{array}$ \\
\hline
\end{tabular}

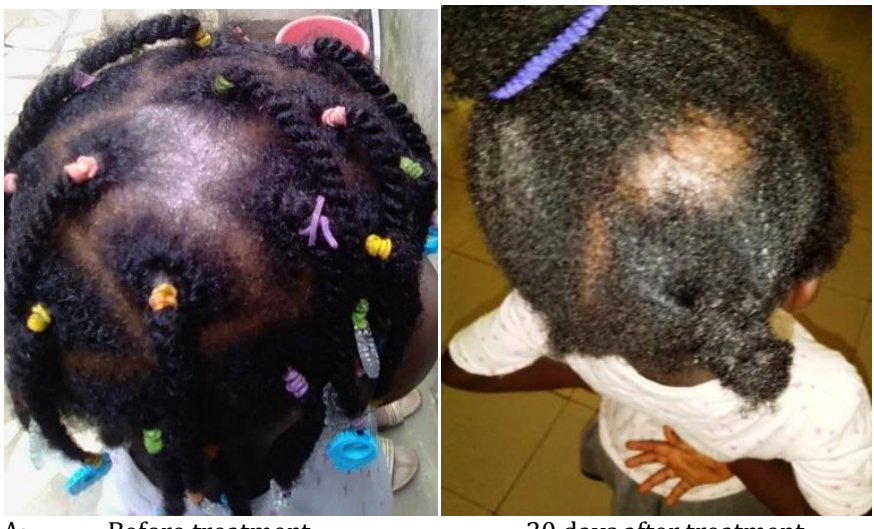

A:

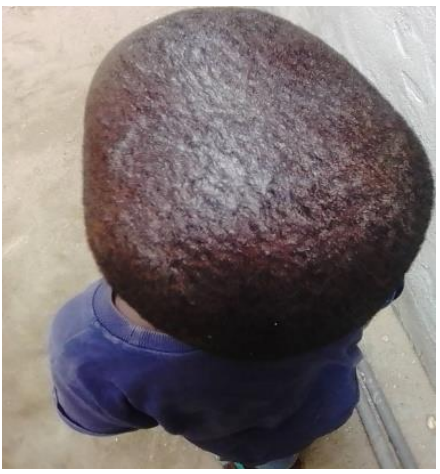

B:

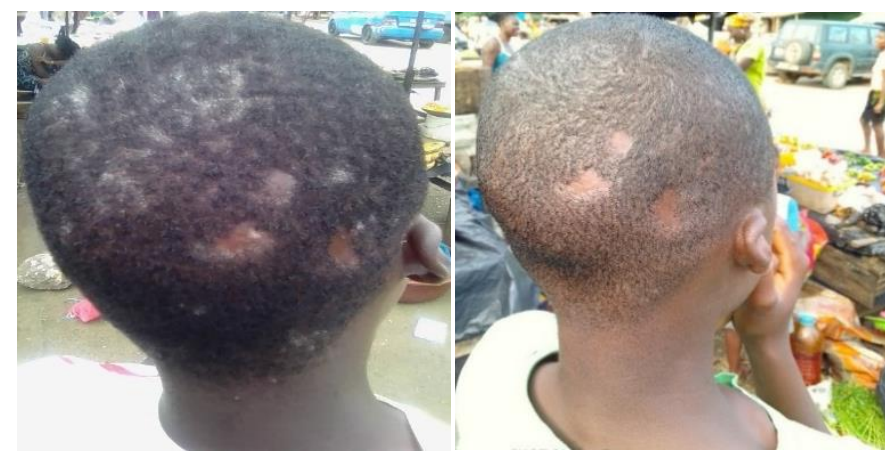

C:

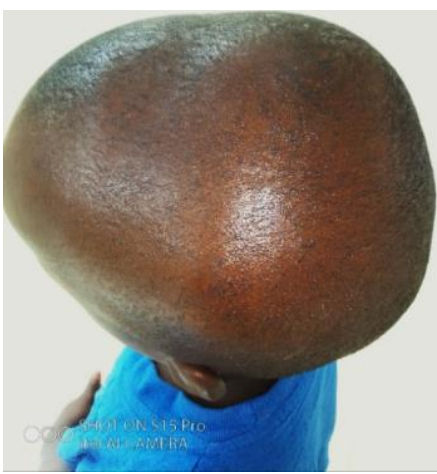

21 days after treatment
Fig. 3 Patients with moths of the scalp. Photo taken by N'guessan, (2019) Scale: 1/3

\subsection{Discussion}

Shea butter was used as an excipient because it easily releases the active ingredient since the cell membrane is mainly made up of phospholipids. According to Eyang [10], shea butter is preferred to other excipients such as vaseline and palm kernel oil because it releases the active ingredients better, it is "organic" compared to vaseline, less messy and has a more pleasant or acceptable smell than palm kernel oil, which is more frequently used externally [11]. The $\mathrm{pH}$ values of the ointments obtained (4.30 - 4.93) are in the order of Eyang [10], which stipulates that a good ointment should have a pH between 4.2 and 5.8. These values would be related to a compatibility between the extract and shea butter, so they do not cause irritation to the skin of users. The ointment has been used to treat cases of moths of the scalp.

Among the twelve children suffering scalp moth and whose ages ranged from 3 to 16 years, only two girls $(16.67 \%)$ were affected. The other ten $(83.33 \%)$ were boys. No adults were identified in our study. According to Causse [12], scalp moth mainly affects children before puberty, especially males rarely in adults.

The treatment lasted on average 21 days, at the end of which total cure is obtained. All patients suffered of clipping moth. No cases of favic moths were noted. These results agree with those of Adou-Bryn et al. [13] who showed that Trichophyton soudanense and Microsporum langeronii are responsible for moths in Ivory Coast. The duration of treatment was shorter than that of earlier workers [13-16] who obtained a cure after 25, 28,30 and 35 days respectively after treatment with ointments and soaps made from plant extracts. This difference could be to the types of extracts and excipients. Of the 12 cases of scalp moths treated, only one case of resistance was observed, with a duration of 2 months of treatment. This 
long duration would be linked to the presence of spores in the patient's environment, lifestyle, and nutritional status, duration of germs on the scalp or immunity. Our results are confirm with Schauder [17] who state that scalp moth treatment is more demanding and longer than that hairless skin moth. This is due to the presence of spores that are not very sensitive to antifungal agents and intra or peripillar location, which may make them less accessible to the therapeutic agent.

The analysis of this result shows compliance with Akakpo-Akué [18]. According to him in the current therapy (use of local and/or general antifungals), a combination of active molecules (antifungal and antiseptic) must necessarily be used for a fairly long period of time of treatment to obtain complete eradication of the pathogenic agent. For the treatment of Pityriasis versicolor, daily application of the antimicrobial ointment $(0.0175 \mathrm{~g} / \mathrm{mL})$ gave healing after 21 days. This treatment is similar to DAEL cream [15]. The duration of treatment (21 days) is slightly shorter than that of [14] who treated Pityriasis versicolor in [23 days]. This difference would be related to the difference in the plant, the affected area, the extent of the condition but also to the form of medication used. The physiological condition of the patient also has an influence in the treatment of a condition.

As Pityriasis versicolor is caused by a yeast, of the genus Malassezia sp., keratinophilic and lipophilic, saprophytes of the human skin, the extract would not only be active on dermatophytes but also on dermatosis.

The various concentrations used in the formulation of the ointment were all active on the various fungal diseases. This analysis shows that the formulated ointment has a good activity on dermatosis. The concentrations ranging from $\mathrm{C} 4$ to $\mathrm{C} 6$ had the best activity on moths as well as the $\mathrm{C} 10$ concentration because it allowed to cure a patient who after several years of treatment was still suffering from trichophytic clipping moths, and the C8 concentration at the level of dermatophytes of the hairless skin had the best activity.

The duration of treatment is justified by the affected area and the dose. The duration of treatment in the hairless skin area is shorter because the hairs are almost absent in the affected areas. Bristles are dermatophytes multiplication zone, making it difficult for the drug to reach the action site [19]. This variability in treatment duration may also be related to noncompliance with the dosage during treatment. In the prevention scalp moths, patient's eviction is not necessary $[20,21]$. Only rules of hygienic practices have to be respected.

\section{Conclusion}

The main objective of this study was to treat moths with an ointment made with extracts of Terminalia ivorensis A. Chev (Combretaceae). The 12 (twelve) people with moths who were treated for 21 days were all cured. It appears from this study, that hydroethanolic extract $70 \%$ of $T$. ivorensis bark has indeed antifungal properties, a virtue granted in traditional environment. The extract incorporated into the shea butter retained the activity of the active ingredients, so the shea butter improved the activity by allowing active ingredient penetration through the skin. The most active concentrations are: C4: $0.01 \mathrm{~g} / \mathrm{mL}$; 5 : $0.0125 \mathrm{~g} / \mathrm{mL}$; C6: 0.015 $\mathrm{g} / \mathrm{mL}$ and $\mathrm{C} 10: 0.025 \mathrm{~g} / \mathrm{mL}$. In perspective, it is hopefully to have a significant number of patients with moth to better evaluate the safety and therapeutic activity of the ointment and to study the interactions between shea butter and the extract to determine the best concentration to determine the optimal dose for the ointment's formulation. However, these initial results are encouraging and make a hope in the fight against moths.

\section{Authors Declaration on Human Study}

The work aimed at scientific confirmation of Terminalia ivorensis traditional use against several skin diseases. The plant is used regularly by people for their care. We had verified this activity by choosing volunteers' adults and children who have been discharged from their parents. This work has been developed in national ethical standards in collaboration with serious laboratories.

\section{Acknowledgements}

Financial support to Biology and Health Laboratory, National Floristic Center from department of Biosciences, Félix Houphouët Boigny, Ivory Coast in Cocody (Abidjan) and the unit of Fundamental Medical Biochemistry of Pasteur Institute (Ivory Coast) are gratefully acknowledged.

\section{References}

[1] S. Rokia, The role of medicinal plants in traditional medicine, Bamako University, Mali, 2006.

[2] A. Michèle, The talks in the mountains, Knowledge of the Valley, Barcelonnette's city. http://www.inra.fr/dpenv/chomic39.htm (Accessed on: July 01, 2019).

[3] W.G. Ma, R.X. Tan, I.N. Fuzzat, Q.S. Li, J.L. Wolfender, K. Hostettmann, Natural occurring and synthetic polyyne glycosides, Phytochem. 45(2) (1997) 411415.

[4] J.E. Hilaly, Z.H.B. Israil, B. Lyoussi, Acute and chronic toxicological studies of Ajugaiva in experimental animals, J. Ethnopharm. 91 (2004) 43-50.

[5] L.F. Biyiti, V. Tamze, N. Nnanga, A.G. Agbor, J. Gangoue-pieboji, Formulation of an antibacterial ointment based on an ethanolic extract of the bark of Tabernaemontana crassa Benth trunk, Eur. Sci. J. 10 (2012) 87-95.

[6] G.F. Ameenah, Medicinal plants: Traditions of yesterday and drugs of tomorrow, Mol. Aspect Med. 27(1) (2006) 1-93.

[7] Anonymous, Skin Diseases-Leem, http://www.leem.org (Accessed on: July 01, 2019).

[8] G. Percebois, Introduction to a study of dermatophytes, Bulletin of the Faculty of Pharmacy, Association of Microbiology Graduates of the Nancy, France, 1973.

[9] N.G. Zirihi, M.K. Adou Kra, F. Guédé-Guina, Evaluation of the antifungal activity of Microglossa pyrifolia (Lamarck) O. Kunze (Asteraceae) on the in vitro growth of Candida albicans, Rev. Afr. Med. Pharmacol. 17 (2003) 11-18.

[10] E.M. Eyang, Study of phytochemistry, antibacterial and antifungal activities of five medicinal plants used in the traditional treatment of dermatosis in Mali, Doctoral thesis of the Faculty of Medicine, Pharmacy and Ondontostomatology, University of Bamako, Mali, 2007.

[11] O.S. Mboui, Traditional palm kernel oil, State Doctorate Thesis, Faculty of Medicine, Pharmacy and Odontostomatology, Cheikh Anta-Diop University, Dakar, 2003.

[12] C. Causse, Zoonotic dermatophytes: current aspects and management in the dispensary, PhD thesis in pharmacy, Joseph Fourier University, COUNTRY, 2011.

[13] K.D. Adou-Bryn, A. Assoumou, R.N. Haddad, B.R. Aka, J. Ouhon, K.J. Brou, Epidemiology of moths in Abidjan (Ivory Coast), Trop. Med. 64 (2004) 171175.

[14] K. Béné, D. Camara, I.A. Soumahoro, Y. Kanga, G.N. Zirihi, Galenic formulation of an antimicrobial ointment based on a hydroethanolic extract of Bersama abyssinica, Fresen Ethnopharm. 58 (2013) 60-69.

[15] A.M. Akakpo-Akué, I.P. Gbery, A.K. Mathieu Kra, G.N. Zirihi, F.H. Yapi, A.J. Djaman, Evaluation of the antifungal activity and clinical trial of a cream formulated with the X12 extract of Terminalia catappa, on some superficial mycosis, Ivor. J. Sci. Technol. 13 (2009) 175-190.

[16] P.M. Thès, Contribution to the development of an antimicrobial soap for cosmetic and medical purposes, Doctoral thesis, UFR Biosciences, University of Cocody, Abidjan, Ivory Coast, 2008.

[17] S. Schauder, Itraconazole in the treatment of Tinea capitis in children, Case reports with long-term followup evaluation, Rev. Lit. Mycoses 45 (2002) 1-9.

[18] A.M. Akakpo-Akué, Formulation of a cream based on MISCA oil, biotech, AED Pharma. S.N., UFR Biosciences Abidjan University, Ivory Coast, 2006.

[19] C. Hauy-Faget, Scalp infections by external agents, Elsevier, COUNTRY, 2010.

[20] D. Chabasse, C. Guiguen, N. Contet-Audonneau, Dermatophytosis : In Medical Mycology, Elsevier, Paris, Masson, 1999.

[21] ANOFEL, Parasitology Mycology, Saint-Maurice $C R$ Useful Format, France, 2004 